\title{
Evaluasi Sistem Plambing, Instalasi Pengolahan Air Limbah dan Pengelolaan Sampah di Rumah Susun Gunung Sari Kota Surabaya
}

\author{
Thariq Miswary dan Hari Wiko Indarjanto \\ Departemen Teknik Lingkungan, Fakultas Teknik Sipil dan Perencanaan, Institut Teknologi Sepuluh Nopember \\ (ITS) \\ e-mail: hwi_corp@yahoo.com
}

\begin{abstract}
Abstrak-Rumah Susun Gunungsari yang terletak di Jalan Gunungsari Kota Surabaya telah selesai dibangun dan mulai beroperasi pada tahun 2011. Terdapat 3 blok bangunan dengan jumlah total unit sebanyak 268 unit. Dari hasil pengamatan awal menunjukkan bahwa rumah susun tersebut mengalami banyak permasalahan pada sistem plambing, pengolahan air limbah maupun pengelolaan sampah. Studi evaluasi diawali dengan pengumpulan data sekunder (gambar as build drawing dan biaya tagihan air per bulan) dan pengumpulan data primer (observasi dan wawancara dengan pihak UPT pengelola dan penghuni Rumah Susun Gunungsari). Data tersebut digunakan sebagai dasar evaluasi lalu dibandingkan dengan kondisi eksisting pada rumah susun tersebut. Acuan evaluasi tersebut berupa standar yang berlaku seperti SNI dan standar-standar lainnya. Pada sistem plambing, terdapat banyak kebocoran dan diameter pipa black water terlalu besar dari ketentuan. Kapasitas roof tank juga tidak mampu menampung air saat penggunaan puncak. Ground reservoar tidak menampung cadangan untuk pemadam kebakaran sehingga perlu dilakukan perluasan sebesar $120 \mathrm{~m}^{3}$ dengan harga Rp.306,014,073.20. Pada pengolahan air limbah eksisting, black water menuju ke tangki septik sedangkan grey water tidak dilakukan pengolahan. Pengolahan grey water direncanakan menggunakan Anaerobic Baffle Reactor dengan harga Rp.211,967,896.20. Pada tangki septik eksisting, pengurasan lumpur yang optimal yaitu 2 tahun sekali. Pada pengelolan sampah, kapasitas gerobak eksisting yaitu $1 \mathrm{~m}^{3}$ tidak mampu menampung sampah selama 2 hari, sehingga gerobak perlu diganti menjadi $2 \mathrm{~m}^{3}$ dan waktu pengangkutan diganti menjadi sehari sekali.
\end{abstract}

Kata Kunci-evaluasi, rumah susun, plambing, fire hydrant, tangki septik, anaerobic baffle reactor, pengelolaan sampah.

\section{PENDAHULUAN}

$\mathrm{S}$ URABAYA merupakan kota terbesar kedua di Indonesia dengan jumlah penduduk 2.848 .583 jiwa dengan pertumbuhan penduduk sebesar $0,52 \%$ [1]. Semakin bertambahnya penduduk maka semakin sedikit ketersediaan lahan di kota Surabaya sehingga menyebabkan banyak masalah, antara lain tumbuhnya perumahan kumuh yang disebabkan oleh banyaknya penduduk yang ingin tinggal di kota. Oleh sebab itu pembangunan rumah vertikal atau rumah susun dirasakan perlu digalakkan, salah satunya adalah Rumah Susun Gunungsari Kota Surabaya yang telah selesai dibangun pada tahun 2011.

Setelah beroperasi selama kurang lebih 5 tahun, rumah susun Gunungsari telah banyak mengalami permasalahan pada prasarana umum. Pada sistem plambing terjadi kebocoran pada pipa-pipa, tidak tercukupinya air saat pagi hari (jam puncak) hingga tersumbat dan meluapnya air dari pipa pembuangan. Begitupula pada sistem pengelolaan limbah cair dan limbah padat, masih banyak yang belum dikelola dengan baik.

Sebuah rumah susun harus memiliki kelengkapan prasarana yang memenuhi standar tertentu untuk kebutuhan tempat tinggal yang layak, sehat, aman, dan nyaman meliputi jaringan jalan, drainase, sanitasi, air bersih, dan tempat sampah [2]. Hal ini yang menyebabkan diperlukannya evaluasi dari sistem plambing, instalasi pengolahan air limbah, dan pengelolaan sampah.

Tujuan dari evaluasi yang dilakukan adalah mengidentifikasi masalah sistem plambing (penyediaan air bersih, penyaluran air buangan, fire hydrant dan talang air hujan), masalah pada instalasi pengolahan air limbah dan masalah pada pengelolaan sampah pada Rumah Susun Gunungsari Kota Surabaya..

\section{METODOLOGI PERANCANGAN}

\section{A. Kerangka Perancangan}

Rangkaian kegiatan perancangan yang terdapat dalam kerangka perancangan dapat diuraikan sebagai berikut:

1) Ide studi

Ide penyusunan tugas akhir ini adalah mengevaluasi sistem plambing, instalasi pengolahan air limbah dan pengelolaan sampah pada rumah susun Gunungsari Kota Surabaya.

2) Studi literatur

Studi literatur merupakan tinjauan pustaka sebagai kegiatan mengumpulkan informasi yang berguna mendapatkan data penunjang untuk kegiatan evaluasi yang berasal dari literatur. Tinjauan pustaka yang dikaji meliputi konsep perencanaan sistem plambing, bangunan pelengkap seperti ground reservoar dan roof tank serta pompa. Lalu instalasi pengolahan air limbah berupa tangki septik dan Anaerobic Baffle Reactor dan sistem pengelolaan sampah yang baik dan benar.

3) Pengumpulan data

Data yang di gunakan untuk evaluasi pada rumah susun Gunungsari Kota Surabaya antara lain:

a. Data Sekunder

Data sekunder yang di perlukan dalam kegiatan evaluasi, antara lain:

- Data jumlah penghuni rumah susun yang diperoleh dari 
UPT Pengelola rumah susun, digunakan untuk mengetahui konsumsi air yang digunakan.

- Data layout dan denah tiap lantai yang diperoleh dari as build drawing rumah susun, digunakan untuk mengetahui tata letak.

- Data gambar sistem perpipaan yang diperoleh dari as build drawing rumah susun, digunakan untuk mengevaluasi sistem perpipaan eksisting.

- Data jenis alat saniter yang diperoleh dari as build drawing rumah susun digunakan untuk menghitung beban alat plambing.

- Curah hujan Kota Surabaya yang diperoleh dari BMKG Kota Surabaya, digunakan untuk mengetahui intensitas hujan yang turun.

b. Data Primer

Data primer yang diperlukan dalam kegiatan evaluasi, antara lain:

- Kebutuhan air penghuni rumah susun dan jam puncak untuk menganalisis kebutuhan reservoar dan roof tank.

- Jenis pipa terpasang untuk menganalisis kesesuaian kebutuhan pipa dengan pipa yang telah terpasang.

4) Evaluasi pada rumah susun

Evaluasi pada rumah susun yang dilakukan meliputi:

1. Kondisi sistem plambing dengan mengacu pada konsep perencanaan sistem plambing yang digunakan di Indonesia, yaitu SNI 8153-2015 tentang tata cara perencanaan sistem plambing bagunan.

2. Kondisi bangunan pelengkap seperti ground reservoar dan roof tank sesuai dengan kebutuhan yang diperlukan.

3. Kondisi instalasi pengolahan air limbah yang berupa tangki septik dengan mengacu pada konsep perencanaan tangki septik yaitu SNI 03-2398-2002 dan konsep perencanaan Anaerobic Baffle Reactor.

4. Kondisi pengelolaan sampah pada tahap pewadahan dan waktu pengangkutan sampah.

\section{HASIL DAN PEMBAHASAN}

\section{A. Evaluasi Sistem Penyediaan Air Bersih}

1) Kebutuhan Air Bersih

Adapun pemakaian air rata-rata per orang sebanyak 170 L/orang/hari untuk penghuni rumah susun Gunungsari, karena alat plambing yang ada adalah kran dan kloset biasa yang membutuhkan air lebih banyak.

$\mathrm{Q}_{1}=$ Jumlah penghuni $x$ Pemakaian Air $=1350$ orang $\times 0.17 \mathrm{~m}^{3} /$ orang/hari $=229.5 \mathrm{~m}^{3} /$ hari

$\mathrm{Qd}=(100 \%+$ Tambahan pemakaian air \% $) \times \mathrm{Q}_{1}$ $=(100 \%+10 \%) \times 229.5 \mathrm{~m}^{3} /$ hari $=252.45 \mathrm{~m}^{3} /$ hari

$\mathrm{Qh}=\mathrm{Qd} / \mathrm{t}$ $=\left(252.25 \mathrm{~m}^{3} / \mathrm{hari}\right) /(10 \mathrm{jam} / \mathrm{hari}) \quad=25.25 \mathrm{~m}^{3} / \mathrm{jam}$

Qh-max $=25.25 \mathrm{~m}^{3} / \mathrm{jam} \times 2=50.49 \mathrm{~m}^{3} / \mathrm{jam}$

Qm-maks $=\left(25.25 \mathrm{~m}^{3} / \mathrm{jam}\right) / 60 \times 3=1.26 \mathrm{~m}^{3} / \mathrm{menit}$

2) Ground Reservoar

Ground Reservoar eksisting dengan panjang $16 \mathrm{~m}$, lebar $4 \mathrm{~m}$ dan kedalaman $2.5 \mathrm{~m}$ dengan volume $160 \mathrm{~m}^{3}$.

Berdasarkan perhitungan ground reservoar yang dibutuhkan untuk menampung air bersih adalah:

$$
\begin{aligned}
& \mathrm{Qs}=(\text { kebutuhan air rata-rata }) /(24 \mathrm{jam}) \\
& \begin{aligned}
& \mathrm{Q} s=\left(252.45 \mathrm{~m}^{3} / \text { hari }\right) /(24 \mathrm{jam})=10.52 \mathrm{~m}^{3} / \mathrm{jam} \\
& \mathrm{V}_{\mathrm{R}}=\mathrm{Q}_{\mathrm{d}}-(\mathrm{Qs} \times \mathrm{T})+\mathrm{V}_{\mathrm{f}}[3] \\
&= 252.45 \mathrm{~m}^{3} / \mathrm{hari}-\left(10.52 \mathrm{~m}^{3} / \mathrm{jam} \times 10 \mathrm{jam} / \mathrm{hari}\right)+ \\
& \mathrm{V}_{\mathrm{f}} \quad=147.3 \mathrm{~m} 3
\end{aligned}
\end{aligned}
$$

Kapasitas ground reservoar eksisting memiliki kapasitas $160 \mathrm{~m}^{3}$ sedangkan berdasarkan perhitungan kapasitas yang harus tersedia untuk menampung kebutuhan air bersih sebesar $147.3 \mathrm{~m}^{3}$. Namun ground reservoar tersebut digunakan untuk menampung kebutuhan air bersih dan cadangan air untuk pemadam kebakaran.

3) Roof Tank

Terdapat 4 roof tank dengan kapasitas tiap roof tank sebesar 2000 Liter. Total kapasitas roof tank yaitu 8000 Liter atau $8 \mathrm{~m}^{3}$. Pemompaan ke roof tank tersebut dilakukan otomatis apabila air pada roof tank mencapai level rendah.

Roof tank tersebut harus mampu menampung air disaat pemakaian puncak. Pemakaian puncak air bersih yaitu sebesar $25.25 \mathrm{~m}^{3} / 30$ menit. Kapasitas roof tank eksisting tidak sesuai dengan kebutuhan.

Solusinya adalah dengan melakukan penambahan debit pemompaan, namun menambah biaya dari operational dan maintanance.

Pada keadaan eksisting, pompa hanya digunakan 2 unit saja, untuk mengatasi hal tersebut maka digunakan 3 unit pompa. Perhitungannya sebagai berikut :

$$
\begin{array}{lll}
\text { 1. Kapasitas pompa } & =300 \mathrm{~L} / \text { menit } \\
\text { 2. Jumlah pompa digunakan } & =3 \mathrm{unit} \\
\text { 3. Total debit pemompaan } & =900 \mathrm{~L} / \text { menit } & \\
\text { 4. Waktu pemompaan } & =30 \mathrm{menit} \\
\text { 5. Volume } & =\mathrm{Tpu} \times \mathrm{Qpu} \\
& =30 \quad \text { menit } \mathrm{x} \quad 900 \\
& \mathrm{~L} / \mathrm{menit} \\
& =27 \mathrm{~m}^{3}
\end{array}
$$

Dengan penambahan penggunaan 1 unit pompa dapat mengatasi kekurangan dari penggunaan air puncak.

4) Dimensi Pipa Air Bersih

Tabel 1.

Perpipaan Air Bersih Eksisting

\begin{tabular}{clc}
\hline \hline No & \multicolumn{1}{c}{ Perpipaan } & D (Inci) \\
\hline 1 & Pipa dari GR ke RT (pipa transfer) & 4 \\
2 & Pipa Shaft dari RT ke Lt 1-5 & 3 \\
3 & Pipa datar dari shaft ke tiap lantai & 2 \\
4 & Pipa datar ke tiap kamar & $3 / 4$ \\
\hline \hline
\end{tabular}

Perhitungan dimensi pipa air bersih menggunakan metode penentuan nilai fixture unit. Nilai fixture unit setiap alat plambing dalam sebuah hunian yaitu :

$$
\begin{aligned}
& \text { Kran } \quad=1 \text { buah } \times 2 \text { FU }=2 \text { FU } \\
& \text { Sink Dapur }=1 \text { buah } \times 2 \text { FU }=2 \mathrm{FU} \\
& \text { Total }=2 \mathrm{FU}+2 \mathrm{FU}=4 \mathrm{FU}
\end{aligned}
$$

Kemudian dilakukan penentuan debit yang mengalir dalam pipa tersebut. Debit yang mengalir pada setiap jalur dapat diketahui dengan memplotkan total beban alat plambing pada jalur dengan kurva. Perhitungan lengkap diameter pipa air bersih dapat dilihat pada Tabel 2, 
sedangkan isometri pipa air bersih pada Gambar 1.

Tabel 2.

Perhitungan Dimensi Pipa Air Bersih

\begin{tabular}{ccccc}
\hline \hline Jalur & UAP & Q (GPM) & Q (L/detik) & D (inci) \\
\hline A1 - A (Sink Dapur) & 2 & 2 & 0.12 & 0.5 \\
A - B & 2 & 2 & 0.12 & 0.5 \\
B1- B (Kran) & 2 & 2 & 0.12 & 0.5 \\
B - C & 4 & 4 & 0.25 & 0.75 \\
C - D & 4 & 4 & 0.25 & 0.75 \\
D - E1 (Shaft) & 112 & 74 & 4.86 & 2 \\
D - E2-5 (Shaft) & 960 & 236 & 14.85 & 2 \\
E1 - E5 (Shaft) & 1072 & 244 & 16.24 & 3 \\
E5 - Roof Tank & 1072 & 244 & 16.24 & 3 \\
\hline Keterangan : & \\
Nilai D - E1 $=$ Nilai UAP 1 Unit x jumlah unit lantai 1 \\
UAP \\
Nilai D - E2-5 = 4 UAP x 240 Unit kamar $=960$ UAP \\
Niali E1 - E5 = 112 UAP + 960 UAP \\
UAP
\end{tabular}

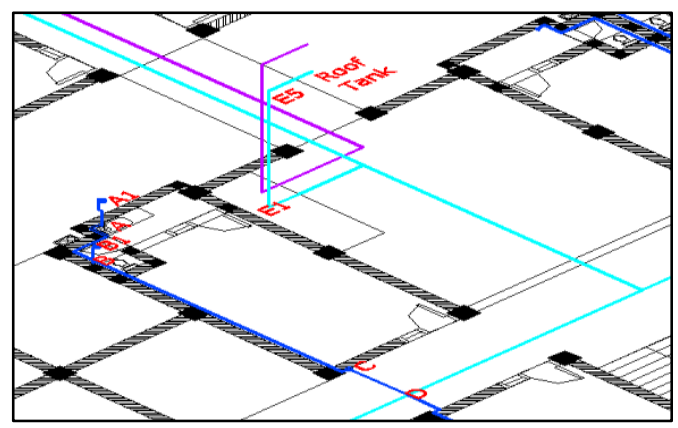

Gambar 1. Isometri Pipa Air Bersih.

Dengan demikian pada beberapa bagian dari sistem pipa tersebut diperoleh diameter yang lebih besar daripada yang ditentukan berdasarkan perhitungan. Sehingga dimensi pipa air bersih eksisting sudah sesuai dengan perhitungan.

\section{5) Pompa Air Bersih}

Pada Rumah Susun Gunungsari Kota Surabaya, pompa air bersih yang digunakan sebanyak 2 buah dan terdapat 2 buah pompa lagi untuk cadangan. Spesifikasi pompa tersebut :

Merk : Sanyo, Jet Water Pump PDH255JP

Kapasitas max : 300 Liter/menit

Head $\quad: 50 \mathrm{~m}$

Berdasarkan perhitungan head pompa menggunakan rumus sebagai berikut:

- Head Statik = 20 meter

- Mayor losses (Hf)

L discharge total : 134 meter

Diameter : 4 inci $\sim 10.16 \mathrm{~cm}$

Debit pengaliran : 13.4 Liter/detik

$\mathrm{Hf}=\left(\frac{Q}{0.00155 \times c \times D^{2,63}}\right)^{1,85} \times L \quad=4.61$ meter

- Minor losses (Hm)
Head akibat 12 belokan $90^{\circ}(\mathrm{K}=0.3) \quad=0.73$ meter

Head akibat 4 valve $(\mathrm{K}=2)$

$=1.63$ meter

Head akibat 2 check valve $(K=2)$

$=0.81$ meter

Jadi total minor losses adalah $\quad=3.17$ meter

Maka total Hf total yaitu $4.61 \mathrm{~m}+3.17 \mathrm{~m}=7.78 \mathrm{~m}$

- $\mathrm{Hp}=20 \mathrm{~m}+7.78 \mathrm{~m}+2 \mathrm{~m}=29.78 \mathrm{~m}$

Berdasarkan perhitungan head pompa sebesar 29.78 meter, sedangkan berdasarkan pompa eksisting mempunyai head pompa sebesar 50 meter, sehingga head pompa berlebih sebesar 20.22 meter. Pompa air bersih yang digunakan sudah sesuai dengan kebutuhan.

B. Evaluasi Sistem Penyediaan Air Buangan

1) Dimensi Pipa Air Buangan

Tabel 3.

Pipa Air Buangan Eksisting

\begin{tabular}{clc}
\hline \hline No & \multicolumn{1}{c}{ Perpipaan } & D (Inci) \\
\hline 1 & Pipa WC ke shaft & 4 \\
2 & Pipa Sink dapur ke shaft & 2 \\
3 & Pipa Floor drain ke shaft & 2 \\
4 & Pipa shaft ke Tangki Septik (BW) & 4 \\
5 & Pipa shaft ke saluran lingkungan (GW) & 4 \\
\hline \hline
\end{tabular}

Perhitungan dimensi pipa air buangan menggunakan metode penentuan nilai fixture unit. Jika diameter pipa air buangan lebih kecil dari diameter perangkap minimum, maka diambil nilai dari diameter perangkap minimum yang sesuai standar untuk tiap alat plambing. Perhitungan dimensi pipa air buangan dapat dilihat pada Tabel 4.

Tabel 4.

Pipa Air Buangan Eksisting

\begin{tabular}{|c|c|c|c|c|c|}
\hline Jalur & $\begin{array}{l}\mathrm{U} \\
\mathrm{A} \\
\mathrm{P}\end{array}$ & $\begin{array}{c}\mathrm{D} \\
\text { min } \\
\text { (inci) }\end{array}$ & $\begin{array}{l}\text { Akumulasi } \\
\text { UAP }\end{array}$ & $\begin{array}{c}\mathrm{D} \\
\text { UAP } \\
\text { (inci) }\end{array}$ & $\begin{array}{c}\mathrm{D} \\
\text { (inci) }\end{array}$ \\
\hline A - B (Sink Dapur) & 2 & 1.5 & 2 & 1.5 & 2 \\
\hline B - X (Floor Drain) & 2 & 2 & 4 & 2 & 2 \\
\hline $\mathrm{C}-\mathrm{Y}(\mathrm{WC})$ & 4 & 3 & 4 & 3 & 3 \\
\hline \multicolumn{6}{|c|}{ Shaft } \\
\hline \multirow{2}{*}{\multicolumn{3}{|c|}{$\begin{array}{l}\text { X (Lantai 5) - Saluran Lingkungan } \\
\text { Y (Lantai 5) - Tanki Septik }\end{array}$}} & 20 & 4 & 4 \\
\hline & & & 20 & 4 & 4 \\
\hline
\end{tabular}

Berdasarkan perhitungan, pipa dari WC menuju ke shaft (black water) diperbolehkan menggunakan pipa berdiameter 3 inci [4], sedangkan pipa eksisting berdiameter 4 inci, sedangkan pipa dari sink dapur dan floor drain menuju ke shaft (grey water) sudah sesuai dengan perhitungan.

\section{Evaluasi Sistem Fire Hydrant}

1) Kebutuhan Air Fire Hydrant

Kebutuhan air untuk fire hydrant ditetapkan berdasarkan jumlah dan jenis alat fire hydrant [5]. Perhitungan kebutuhan air adalah sebagai berikut:

- Box Hydrant dalam gedung

$\mathrm{Q}=400$ Liter/menit

$\mathrm{t} \quad=15$ menit

$\mathrm{n}=6$ buah

$\mathrm{V}=\mathrm{Q} \times \mathrm{t} \times \mathrm{n} \quad=36000$ Liter $=36 \mathrm{~m}^{3}$

Pillar Hydrant luar gedung 
$\mathrm{Q}=800 \mathrm{Liter} / \mathrm{menit}$

$\mathrm{t}=30$ menit

$\mathrm{n}=4$ buah

$\mathrm{V}=\mathrm{Q} \times \mathrm{t} \times \mathrm{n}=96000$ Liter $=96 \mathrm{~m}^{3}$

Maka kebutuhan air fire hydrant adalah sebesar $132 \mathrm{~m}^{3}$.

Berdasarkan perhitungan kebutuhan air fire hydrant, dapat dihitung kapasitas ground reservoar, tujuannya adalah untuk mengatasi kekurangan air jika terjadi kebakaran.

$\mathrm{V}_{\mathrm{R}}=$ Vair bersih $+\mathrm{V}_{\mathrm{f}}$

$V_{R}=147.3 \mathrm{~m}^{3}+132 \mathrm{~m}^{3}=279.3 \mathrm{~m}^{3}$

Ground reservoar eksisting hanya mempunyai kapasitas sebasar $160 \mathrm{~m}^{3}$, sehingga untuk menutupi kekurangan air yang dibutuhkan perluasan kapasitas ground reservoar. Perluasan ground reservoar dapat dilihat pada Gambar 2.

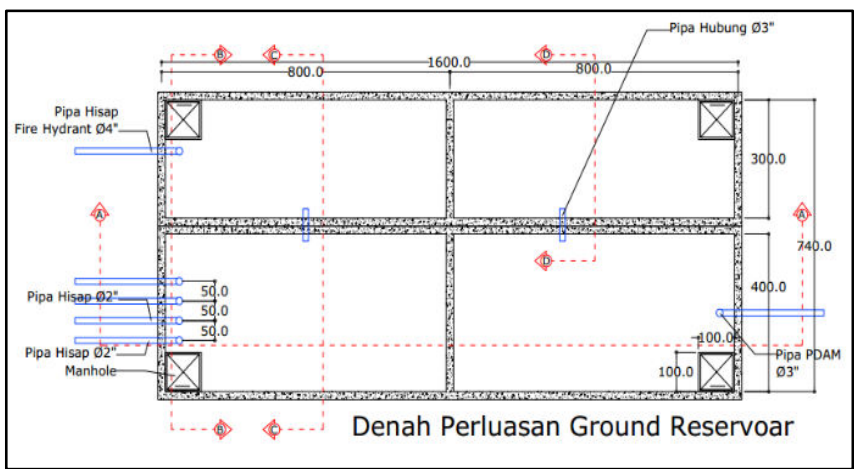

Gambar 2. Perluasan Ground Reservoar

\section{Evaluasi Sistem Penyaluran Air Hujan}

1) Menentukan Intensitas Hujan

Nilai intensitas hujan ditentukan untuk menghitung lamanya hujan yang diperlukan air dari atap bangunan untuk sampai ke perpipaan air hujan.

Tinggi atap $=6 \mathrm{~m}$

Panjang Atap $=48 \mathrm{~m}$

Lebar Atap $\quad=20 \mathrm{~m}$

Lebar atap miring $=\sqrt{\text { tinggi atap }^{2}+\left(\frac{\text { lebaratap }}{2}\right)^{2}}$

$$
=12 \mathrm{~m}
$$

Slope atap

$$
=\frac{\text { tinggi atap }}{\frac{\text { lebar atap }}{2}}=0.6
$$

Menentukan TC $=0.0195 \times\left(\frac{L}{\sqrt{S}}\right)^{0.77}=0.16$ menit

Menentukan I $=\frac{R_{24}}{24} x\left(\frac{24}{t c}\right)^{2 / 3}=63.30 \mathrm{~mm} / \mathrm{jam}$

2) Perencanaan Perpipaan Air Hujan

Pada Rumah Susun Gunungsari belum memiliki perpipaan air hujan, sehingga akan dilakukan perencanaan sistem penyaluran air hujan.

Faktor yang mempengaruhi dalam perencanaan dimensi perpipaan air hujan adalah nilai intensitas hujan dan luasan atap. Semakin besar intensitas hujan dan luasan atap maka semakin besar pula dimensi perpipaan air hujan karena beban air hujan yang harus dialirkan juga semakin besar. Penentuan diameter talang horizontal dengan kemiringan sebesar 4\% adalah sebesar 5 inci. Sedangkan diameter pipa tegak air hujan sebesar 4 inci.

\section{E. Evaluasi Instalasi Pengolahan Air Limbah}

Pada Rumah Susun Gunungsari Kota Surabaya hanya black water yang dilakukan pengolahan secara sederhana di tangki septik, sedangkan grey water tidak dilakukan pengolahan lebih lanjut dan akan mengakibatkan pencemaran badan air sehingga perlu dilakukan perencanaan Anaerobic Baffle Reactor. Sample uji lab terhadap limbah grey water dapat dilihat pada Tabel 5 .

Tabel 5.

Karakteristik Limbah Grey Water Rusun Gunungsari

$$
\text { No Parameter Satuan } \begin{gathered}
\text { BakuMutu Air } \\
\text { Limbah Domestik Analisa }
\end{gathered}
$$

\begin{tabular}{ccccc}
\hline 1 & $\mathrm{pH}$ & - & $6-9$ & 6.95 \\
\hline 2 & $\mathrm{TSS}$ & $\mathrm{mg} / \mathrm{L}$ & 50 & 124.00 \\
\hline 3 & $\mathrm{COD}$ & $\mathrm{mg} / \mathrm{L} \mathrm{O}_{2}$ & 50 & 114.00 \\
\hline 4 & $\mathrm{BOD}$ & $\mathrm{mg} / \mathrm{L} \mathrm{O}_{2}$ & 30 & 68.00 \\
\hline 5 & $\begin{array}{c}\text { Minyak } \\
\text { \& Lemak }\end{array}$ & $\mathrm{mg} / \mathrm{L}$ & 10 & 8.00 \\
\hline
\end{tabular}

\section{1) Tangki Septik}

Jumlah tangki septik sebanyak 12 buah dengan kapasitas tiap tanki septik sebesar $20 \mathrm{~m}^{3}$ dengan dimensi $4 \mathrm{~m} \times 2.5 \mathrm{~m}$ x $2.2 \mathrm{~m}$. Setiap tangki septik menerima beban black water maksimum dari 25 unit.

Debit air bersih $=170$ Liter/orang.hari

Debit air limbah = Debit air bersih x 80\%

$$
=136 \text { Liter/orang.hari }
$$

Debit puncak air limbah dapat diketahui melalui nilai faktor puncak. Jumlah penghuni rumah susun $(\mathrm{P})=1350$ orang (1340 penghuni dan 10 orang pegawai UPT)

$$
\mathrm{f}_{\mathrm{p}}=\frac{18+\mathrm{P}^{0.5}}{4+\mathrm{P}^{0.5}}=1.35
$$

Jika tangki septik hanya untuk black water saja, maka jumlah produksi lumpur adalah 25 L/orang.tahun [6].

UPT Pengelola Rumah Susun Gunungsari Kota Surabaya biasanya melakukan pengurasan lumpur setiap 3 tahun sekali. Maka volume lumpur adalah:

$$
\begin{aligned}
\text { VLumpur } & =\mathrm{P} \times \mathrm{N} \times \mathrm{S} \\
\text { VLumpur } & =125 \text { orang } \times 3 \text { tahun } \times 25 \text { L/orang.tahun } \\
& =9375 \text { Liter } \sim 9.38 \mathrm{~m}^{3} \\
\text { Tinggi lumpur } & =\frac{\text { VLumpur }}{\text { (lebar } \times \text { panjang bawah)tangki septik }} \\
& =1.23 \mathrm{~m}
\end{aligned}
$$

Tinggi total tangki septik adalah 2.2 meter, tinggi pipa inlet pada ketinggian 1.9 meter dan tinggi pipa outlet pada ketinggian 1.8 meter sedangkan tinggi lumpur 1.23 meter (melebih dari sepertiga tinggi total air) sehingga waktu pengurasan setiap 3 tahun dirasa tidak efektif sehingga jangka waktu pengurasan dikurangi menjadi setiap 2 tahun sekali. Maka perhitungan volume lumpur adalah:

VLumpur $=\mathrm{P} \times \mathrm{N} \times \mathrm{S}$

VLumpur $=125$ orang $\times 2$ tahun $\times 25$ L/orang.tahun $=6250$ Liter $\sim 6.25 \mathrm{~m}^{3}$

Tinggi lumpur $=\frac{\text { VLumpur }}{(\text { lebar } x \text { panjang bawah }) \text { tangki septik }}$ 


$$
=0.82 \mathrm{~m}
$$

Bila pengurasan lumpur dilakukan setiap 2 tahun sekali, maka tinggi lumpur $0.82 \mathrm{~m}$ (lebih sedikit dari sepertiga tinggi total air) sehingga waktu pengurasan setiap 2 tahun dirasa sangat efektif.

2) Anaerobic Baffle Reactor

Bak Pengendap

$\mathrm{SS} / \mathrm{COD}=0.42$ (rencana) $(0.35-0.45)$ [7]

HRT $=3$ jam (rencana)

Penyisihan COD BP $=28 \%$

Penyisihan BOD BP $=30 \%$

Penyisihan TSS BP $=60 \%$

BOD tersisihkan $=$ Rem BOD $\times$ BODin $=20.40 \mathrm{mg} / \mathrm{L}$

COD tersisihkan $=$ Rem COD $\times$ CODin $=31.92 \mathrm{mg} / \mathrm{L}$

TSS tersisihkan $=$ Rem TSS $\times$ TSSin $=74.40 \mathrm{mg} / \mathrm{L}$

Periode pengurasan $\quad=24$ bulan (rencana)

Volume lumpur removal $\quad=66.4 \%$

Massa lumpur setelah stabilisasi $=3618.5 \mathrm{Kg} / \mathrm{hari}$

Densitas lumpur $\quad=1.08 \mathrm{Kg} / \mathrm{L}$

Volume lumpur $\quad=3.35 \mathrm{~m}^{3} /$ hari

Dimensi bak pengendap

Volume cairan = Qtotal $\mathrm{x}$ HRT

$$
=\left(198.29 \mathrm{~m}^{3} / \text { hari : } 24 \mathrm{jam} / \mathrm{hari}\right) \times 3 \mathrm{jam}
$$$$
=24.79 \mathrm{~m} 3
$$

Volume BP = Volume lumpur + volume cairan

$$
=3.35 \mathrm{~m}^{3}+24.79 \mathrm{~m}^{3}
$$$$
=28.14 \mathrm{~m}^{3}
$$

Kedalaman efektif $=2.7 \mathrm{~m}$

Freeboard $\quad=0.3 \mathrm{~m}$

Kedalaman total $=3.0 \mathrm{~m}$

Lebar $\quad=2.5 \mathrm{~m}$ (rencana)

Panjang $\quad=\left(28.14 \mathrm{~m}^{3}\right) /(2.7 \mathrm{~m} \mathrm{x} 2.5 \mathrm{~m})$

$$
=4.2 \mathrm{~m}
$$

Kedalaman lumpur $=\left(3.35 \mathrm{~m}^{3}\right) /(4.2 \mathrm{~m} \times 2.5 \mathrm{~m})$

$$
=0.32 \mathrm{~m}
$$

Kedalaman cairan $=\left(24.79 \mathrm{~m}^{3}\right) /(4.2 \mathrm{~m} \times 2.5 \mathrm{~m})$

$$
=2.37 \mathrm{~m}
$$

Effluen Bak Pengendapan

BODef BP $\quad=68 \mathrm{mg} / \mathrm{L}-20.40 \mathrm{mg} / \mathrm{L}$ $=47.60 \mathrm{mg} / \mathrm{L}$

CODef BP $\quad=114 \mathrm{mg} / \mathrm{L}-31.92 \mathrm{mg} / \mathrm{L}$ $=82.08 \mathrm{mg} / \mathrm{L}$

TSSef BP $\quad=124 \mathrm{mg} / \mathrm{L}-80.60 \mathrm{mg} / \mathrm{L}$

$$
=49.60 \mathrm{mg} / \mathrm{L}
$$

$\underline{\text { Kompartemen }}$

$$
\begin{aligned}
& \text { Dimensi kompartemen } \\
& \text { HLR = } 22 \mathrm{~m}^{3} / \mathrm{m}^{2} \text {.hari }\left(16.8-38.4 \mathrm{~m}^{3} / \mathrm{m}^{2}\right. \text {.hari) [7] } \\
& \text { A surface (As) = Qtot : HLR } \\
& =198.29 \mathrm{~m}^{3} / \text { hari }: 22 \mathrm{~m}^{3} / \mathrm{m}^{2} \text {.hari } \\
& =9.01 \mathrm{~m}^{2} \\
& \text { Lebar } \quad=2.5 \mathrm{~m} \text { (rencana) } \\
& \text { Panjang kompartemen }=\text { As }: \text { Lebar } \\
& =9.01 \mathrm{~m}^{2}: 2.5 \mathrm{~m} \\
& =3.7 \mathrm{~m} \\
& =198.29 \mathrm{~m}^{3} / \text { hari }:(2.5 \mathrm{~m} \times 3.7 \mathrm{~m})
\end{aligned}
$$

$$
=21.44 \mathrm{~m}^{3} / \mathrm{m}^{2} \text {.hari }
$$

Cek kecepatan up flow $=0.89 \mathrm{~m} / \mathrm{jam}$

HRT $=9$ jam (rencana) $(6-20 \mathrm{jam})$ [7]

$\mathrm{H}$ total $=$ HLR $\times$ HRT

$$
=21.44 \mathrm{~m}^{3} / \mathrm{m}^{2} \text {.hari } x(9 \mathrm{jam}: 24 \mathrm{jam} / \text { hari })
$$$$
=8.04 \mathrm{~m}
$$

$\mathrm{H}$ efektif $=2.7 \mathrm{~m}$ (rencana)

Jumlah kompartemen $=\mathrm{H}$ total $: \mathrm{H}$ efektif

$$
\begin{aligned}
& =8.04 \mathrm{~m}: 2.7 \mathrm{~m} \\
& =3 \text { kompartemen }
\end{aligned}
$$$$
\text { Cek OLR } \quad=0.13 \mathrm{Kg} / \mathrm{m}^{3} \text {.hari }(\mathrm{OK})
$$$$
\text { Cek HRT } \quad=9.07 \text { jam }(\mathrm{OK})
$$

Efisiensi removal kompartemen

Faktor overload $\quad=1$

Faktor strength $\quad=0.73$

Faktor temperatur $\quad=1$

Faktor HRT $\quad=0.75$

Faktor jumlah kompartemen $=0.9$

Removal BOD kompartemen $=1 \times 0.73 \times 1 \times 0.75 \times 0.9$

$$
=49 \%
$$

Faktor penyisihan COD $\quad=0.95$.

Removal COD kompartemen $=49 \% \times 0.95$

$$
=46 \%
$$

Removal TSS kompartemen $=70 \%$.

$\begin{aligned} \text { BOD tersisihkan } & =49 \% \times 47.60 \mathrm{mg} / \mathrm{L} \\ & =23.45 \mathrm{mg} / \mathrm{L}\end{aligned}$

COD tersisihkan

$=46 \% \times 82.08 \mathrm{mg} / \mathrm{L}$

$=38.16 \mathrm{mg} / \mathrm{L}$

TSS tersisihkan

$=70 \% \times 49.60 \mathrm{mg} / \mathrm{L}$

$=34.72 \mathrm{mg} / \mathrm{L}$

Effluen ABR

Qef ABR

$=198.29 \mathrm{~m} 3 /$ hari

BODef ABR

$=47.60 \mathrm{mg} / \mathrm{L}-23.45 \mathrm{mg} / \mathrm{L}$

$=24.15 \mathrm{mg} / \mathrm{L}$

CODef ABR

$=82.08 \mathrm{mg} / \mathrm{L}-38.16 \mathrm{mg} / \mathrm{L}$

$=43.92 \mathrm{mg} / \mathrm{L}$

TSSef ABR

$=43.40 \mathrm{mg} / \mathrm{L}-34.72 \mathrm{mg} / \mathrm{L}$

$=14.88 \mathrm{mg} / \mathrm{L}$

Dimensi Total ABR

Lebar ABR

$=2.5 \mathrm{~m}$

Kedalaman efektif

$=2.7 \mathrm{~m}$

Freeboard

$=0.3 \mathrm{~m}$

Panjang bak pengendap $\quad=4.3 \mathrm{~m}$

Panjang tiap kompartemen $\quad=3.7 \mathrm{~m}$

Tebal dinding tiap kompartemen $=0.15 \mathrm{~m}$

Jumlah kompartemen $=3$ buah

Panjang total kompartemen $\quad=11.7 \mathrm{~m}$

Panjang total ABR

$=16 \mathrm{~m}$

Rancangan Anaerobic Baffle Reactor (ABR) tersebut sudah dapat mengolah air limbah mencapai baku mutu Peraturan Gubernur Jawa Timur Nomor 72 Tahun 2013.

Effluen dapat dilihat pada Tabel 6. Rancangan ABR dapat dilihat pada Gambar 3.

Tabel 6.

Efluen Air Limbah Setelah Pengolahan 


\begin{tabular}{|c|c|c|c|c|c|c|c|c|c|}
\hline \multirow{2}{*}{ No } & \multirow{2}{*}{ Parameter } & \multirow{2}{*}{$\begin{array}{l}\text { Influen } \\
\text { (mg } L)\end{array}$} & \multicolumn{2}{|c|}{ Grense Trap } & \multicolumn{2}{|c|}{ BPABR } & \multicolumn{2}{|c|}{$\begin{array}{c}\text { Kompartemen } \\
\mathrm{ABR} \\
\end{array}$} & \multirow{2}{*}{ BalunMưu } \\
\hline & & & $\% R$ & $\begin{array}{l}\text { Efluen } \\
(\mathrm{mg} \mathrm{L})\end{array}$ & $\% R$ & $\begin{array}{l}\text { Efluen } \\
(\operatorname{mg} L)\end{array}$ & $\% R$ & $\begin{array}{l}\text { Eflven } \\
(\mathrm{mg} \mathrm{L})\end{array}$ & \\
\hline $\mathrm{l}$ & TSS & 124.00 & $\%$ & 124.00 & $60 \%$ & 49.60 & $70 \%$ & 14.88 & 50 \\
\hline 2 & COD & 114.00 & $\%$ & 114.00 & $28 \%$ & 82.08 & $46 \%$ & 43.92 & 50 \\
\hline 3 & BOD & 68.00 & $\% \%$ & 68.00 & $30 \%$ & 47.60 & $49 \%$ & 24.15 & 30 \\
\hline 4 & Minyak \& Lemak & 8.00 & $95 \%$ & 0.40 & $\%$ & 0.40 & $0 \%$ & 0.40 & 10 \\
\hline
\end{tabular}

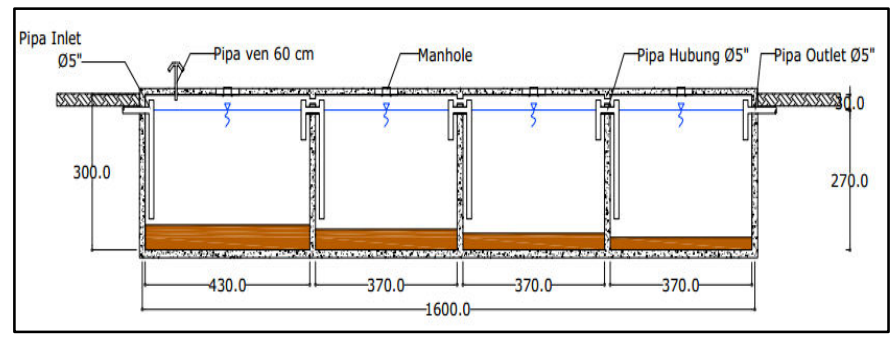

Gambar 3. Potongan A-A Anaerobic Baffle Reactor.

\section{F. Evaluasi Pengelolaan Sampah}

Rumah Susun Gunungsari hanya menyediakan tempat sampah komunal yang dihubungkan dengan shaft sampah. Untuk mengumpulkan sampah tersebut, pada dasar shaft sampah tersebut diletakkan gerobak sampah dengan kapasitas $1 \mathrm{~m}^{3}$. Waktu pengangkutan sampah dari gerobak sampah menuju ke TPS terdekat sebanyak 2 kali sehari.

1) Analisis Timbulan Sampah

Untuk mengetahui timbulan sampah perlu dilakukan sampling langsung pada Rumah Susun Gunungsari [8]. Berikut adalah perhitungan timbulan sampah untuk 1 shaft:

$$
\begin{aligned}
& \text { Jumlah unit terlayani } \quad=134 \text { unit } \\
& \text { Jumlah penghuni } \quad=134 \text { unit } \mathrm{x} 5 \text { orang } \\
& =670 \text { orang } \\
& \text { Berat Total sampah } \quad=304 \mathrm{Kg} / 2 \text { hari pengumpulan } \\
& =152 \mathrm{Kg} / \mathrm{hari} \\
& \text { Berat rata-rata sampah }=(152 \mathrm{Kg} / \mathrm{hari}) /(670 \text { orang }) \\
& =0.23 \mathrm{Kg} / \text { orang.hari } \\
& \text { Dimensi gerobak eksisting }=1.3 \mathrm{~m} \times 0.9 \mathrm{~m} \times 0.8 \mathrm{~m} \\
& \text { Tinggi sampah digerobak }=0.8 \mathrm{~m} \\
& \text { Vol. sampah digerobak }=0.9 \mathrm{~m}^{3} \\
& \text { Berat sampah digerobak }=137 \mathrm{Kg} \\
& \text { Densitas sampah gerobak }=(137 \mathrm{Kg}) /\left(0.9 \mathrm{~m}^{3}\right) \\
& =152.23 \mathrm{~kg} / \mathrm{m}^{3} \\
& \text { Volume sampah total } \quad=(304 \mathrm{Kg}) /\left(152.23 \llbracket \mathrm{kg} / \mathrm{m} \rrbracket^{3}\right) \\
& =1.99 \mathrm{~m}^{3} \\
& \text { Volume sampah per orang }=\left(1.99 \mathrm{~m}^{3}\right) /(670 \text { orang }) \\
& =0.0029 \mathrm{~m}^{3} / \text { orang.hari } \\
& =2.9 \text { L/orang.hari }
\end{aligned}
$$

Dari hasil sampling timbulan tersebut, volume sampah per orang selama 1 hari adalah 2.9 L/orang.hari.

2) Pewadahan dan Waktu Pengangkutan

Perhitungan kapasitas pewadahan sampah untuk blok A dan $\mathrm{C}$ adalah sebagai berikut:

Contoh Perhitungan Blok A

Jumlah penghuni $=670$ orang

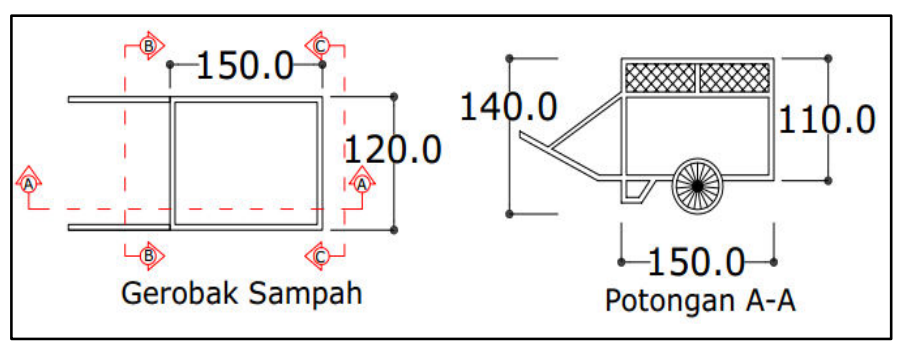

Gambar 4. Gerobak Sampah Baru.

Volume timbulan $\quad=2.9 \mathrm{~L} /$ orang $/ \mathrm{hari}$

Volume sampah total $=670$ orang $\times 2.9 \mathrm{~L} /$ orang/hari

$$
=1.93 \mathrm{~m}^{3} / \text { hari }
$$

Volume gerobak $=1 \mathrm{~m}^{3}$ (gerobak eksisting)

Selisih volume $\quad=0.93 \mathrm{~m}^{3}$

Berdasarkan perhitungan, kapasitas gerobak eksisting tidak mampu menampung sampah yang dihasilkan oleh penghuni blok A maupun blok $\mathrm{C}$, sehingga untuk mengatasi hal tersebut adalah dengan mengganti gerobak sampah.

Gerobak baru tersebut memiliki kapasitas sekitar $2 \mathrm{~m}^{3}$, dapat dilihat pada Gambar 4.

\section{KESIMPULAN}

1. Sistem penyediaan air bersih berfungsi dengan baik dan sudah sesuai dengan SNI 8153-2015. Sistem penyaluran air buangan, diameter pipa black water eksisting terlalu besar dari hasil perhitungan. Sistem fire hydrant masih beroperasi dan sudah sesuai dengan SNI 03-1735-2000.

2. Ground reservoar tidak memenuhi kebutuhan sehingga ground reservoar perlu diperluas dan roof tank tidak memenuhi kebutuhan pemakaian puncak.

3. Pengurasan lumpur pada tangki septik yang optimal dilakukan selama 2 tahun sekali. Pengolahan limbah grey water yang tepat adalah dengan Anaerobic Baffle Reactor.

4. Gerobak eksisting tidak mampu menampung sampah bila dilakukan pengangkutan tiap 2 hari sekali, sehingga diganti dengan gerobak dengan kapasitas $2 \mathrm{~m}^{3}$ dan pengangkutan dilakukan tiap hari sekali.

\section{DAFTAR PUSTAKA}

Badan Pusat Statistik, "Surabaya Dalam Angka 2015," Surabaya, 2016.

Pemerintah Republik Indonesia, "Undang-Undang Republik Indonesia No. 20 Tahun 2011 tentang Rumah Susun," Jakarta, 2011. 
Plambing. Jakarta: Pradnya Paramita, 2000.

[4] Badan Standarisasi Nasional, "SNI 8153-2015: Sistem Plambing Pada Bangunan Gedung,” Jakarta, 2015.

[5] Badan Standarisasi Nasional, "SNI 03-1735-2000: Tata Cara Perencanaan Akses Bangunan Dan Akses Lingkungan Untuk Pencegahan Bahaya Kebakaran Pada Bangunan Gedung,” Jakarta, 2000.

[6] Human Waste Disposal, "Sanitation Improvement Programs," 1987.
[7] L. Sasse, B. Gutterer, T. Panzerbieter, and T. Reckerzügel, Decentralised Wasterwater Treatment Systems (DEWATS) and Sanitattion in Developing Countries. Borda, 2009.

[8] Badan Standarisasi Nasional, "SNI 19-3694-1994: Metode Pengambilan Dan Pengukuran Sampah Contoh Timbulan Dan Komposisi Sampah Perkotaan,” Jakarta, 1994. 